\title{
PENDIDIKAN MULTIKULTURAL DALAM PEMBELAJARAN IPS DI SMP NEGERI 1 LASEM
}

\author{
Oleh: Akhmad Zaini, Agus fathoni Prasetyo
}

\begin{abstract}
Abstrak
Tujuan umum IPS ialah mengembangkan cara berpikir kritis dan kreatif dalam melihat hubungan manusia dan lingkungan hidupnya. Jadi, mempunyai fungsi "membentuk sikap rasional dan tanggung jawab terhadap masalah yang timbul akibat interaksi antara manusia dengan lingkunganya". Pendekatan integratif sesuai realitas kehidupan sosial dan pendekatan struktural yang mengenai penguasaan konsep. Objek IPS adalah gejala-gejala sosial yang teramati yang dapat mengungkap masalah-masalah sosial. Kegiatan pembelajaran IPS merupakan salah satu mata pelajaran yang strategis untuk menanamkan nilai-nilai moral kepada peserta didik. Kirschenbaum menegaskan, bahwa tujuan akhir dari studi Ilmu Pengetahuan Sosial (IPS) adalah diarahkan untuk tercapainya tujuan pendidikan moral.

Tujuan utama IPS adalah mengembangkan potensi peserta didik agar menjadi warga negara yang memiliki sikap, ketrampilan, dan pengetahuan yang memadai sebagai bekal untuk berperan serta dalam kehidupan bermasyrakat yang demokratis. IPS sebagai program pendidikan atau mata pelajaran dalam kurikulum sekolah bertujuan untuk mempelajari kehidupan manusia dalam masyarakat dan hubungan antara sesama manusia atau dengan lingkunganya.

Faktor pendukung penerapan pembelajaran IPS berbasis multikultural di SMP Negeri 1 Lasem tidak hanya karena aneka ragam agama dan budaya yang dimiliki siswa siswinya saja. Namun dengan adanya aneka ragam tersebut terciptalah rasa saling menghargai dan menghormati ditengah perbedaan yang dimiliki siswa SMP Negeri 1 Lasem. Sikap saling menghargai dan menghormati antar siswa tidak hanya dapat dijumpai dalam kegiatan belajar di sekolah saja. Namun, terlebih ketika ada perayaan hari besar agama ataupun bulan puasa Islam dapat terlihat jelas bagaimana kerukunan umat beragama saling menghargai dan menghormati dengan umat beragama yang berbeda.
\end{abstract}

Kata Kunci: Pembelajaran IPS, Pendidikan Multikultur

\section{A. Latar Belakang}

Pendidikan merupakan salah satu upaya untuk meningkatkan kualitas sumber daya manusia, baik secara pribadi maupun sebagai modal dasar pembangunan bangsa. Dalam proses belajar mengajar, guru tidak hanya menyampaikan materi tetapi juga harus berupaya agar materi pelajaran yang disampaikan dapat benar-benar dipahami dan dimengerti siswa, sehingga nilai-nilai yang terkandung dalam materi tersebut dapat membawa siswa untuk diterapkan dalam kehidupan bermasyarakat. Dengan demikian proses pembelajaran lebih bermakna(Puspitasari, 2012:99).

Tujuan umum IPS ialah mengembangkan cara berpikir kritis dan kreatif dalam melihat hubungan manusia dan lingkungan hidupnya. Jadi, mempunyai fungsi "membentuk sikap rasional dan tanggung jawab terhadap masalah yang timbul akibat interaksi antara manusia dengan 
lingkunganya". Pendekatan integratif sesuai realitas kehidupan sosial dan pendekatan struktural yang mengenai penguasaan konsep. Objek IPS adalah gejala-gejala sosial yang teramati yang dapat mengungkap masalah-masalah sosial.

Adapun gambaran keterkaitan antara mata pelajaran dengan nilai yang dapat dikembangkan untuk pendidikan karakter dalam mata pelajaran IPS tingkat SMP yaitu religius, jujur, toleransi, disiplin, kerja keras, kreatif, mandiri, rasa ingin tahu, cinta tanah air, menghargai prestasi, bersahabat, senang membaca, peduli sosial, peduli lingkungan (Kemendiknas, 2010:47).

Multikultural menekankan adanya perbedaan masyarakat berdasarkan kelompok yang didasarkan pada etnisitas. Dari pernyataan tersebut, maka interaksi sosial yang terjadi antar suatu kelompok sosial dalam kehiduapan masyarakat yang multikultur dilakukan dengan cara menemukan identitas dirinya yang didasarkan pada sebuah etnis itu sendiri. Multikultural melihat bagaimana keragaman manusia pada tingkat kelompok atau golongan dan kelompok dan dalam multicultural etnisitas terkesan menitik beratkan. Beberapa kelompok etnik yang ada di Indonesia juga hidup secara berdampingan sehingga dapat terjalin interaksi sosial satu sama lain. Interaksi yang terjadi antara kelompok etnis yang hidup dan berkembang di Indonesia adalah wujud dari etnisitas, yang termasuk dalam suatu kelompok etnik( Yusuf, 2005: 26 ).

Tiongkok Kecil di Tanah Jawa merupakan sebutan untuk kota Lasem karena memiliki banyak pemukiman China, rumah candu yang terkenal pada zamannya, dan tentu saja keberadaan beberapa kelenteng di Lasem mengukuhkan julukan tersebut. Di lain pihak kota ini juga mendapat julukan kota Santri karena memang faktanya di kota Lasem banyak memiliki pesantren, bahkan salah satu Desa di Lasem memiliki 8 pesantren yang saling berdampingan.Masih banyak peninggalan sejarah budaya yang masih berdirikokoh, sebagai bukti bahwa di Lasem terdapat berbagai budaya yang beragam danmempunyai pluralistik menuju masyarakat multikultural(Aziz, 2014:11). Penelitian ini bertujuan untuk menganalisis nilai-nilai multikultural dalam masyarakat Lasem dan menganalisis penerapan pembelajaran IPS berbasis pendidikan multikultural di SMP Negeri 1 Lasem.

\section{B. Kajian Teori}

James A. Banks dikenal sebagai perintis pendidikan multikultural. Penekanan dan perhatiannyadifokuskan pada pendidikannya. James Banks (1993:3) mendefinisikan pendidikan multikultural sebagai pendidikan untuk people of color. Artinya, pendidikan multikultural ingin mengeksplorasi perbedaan sebagai keniscayaan (anugerah Tuhan/sunatullah)

James Bank (1994), pendidikan multikultural memiliki beberapa dimensi yang saling berkaitan satu dengan yang lain, yaitu : Pertama, Content Intergration, yaitu mengintegrasikan berbagai budaya dan kerealisasi dan teori dalam mata pelajaran/disiplin ilmu. Kedua, the knowledge 
construction process, yaitu membawa siswa untuk memahami implikasi budaya ke dalam sebuah mata pelajaran ( disiplin ). Ketiga,an equity paedagogy, yaitu menyesuaikan metode pengajaran dengan cara belajar siswa dalam rangka memfasilitasi prestasi akademik siswa yang beragam baik dari segi ras, budaya ataupun sosial. Keempat, prejudice reduction, yaitu mengidentifikasi karakteristik ras siswa dan menetukan metode pengajaran mereka.

Secara umum pembelajaran dapat diartikan sebagai upaya mewariskan kebudayaan kepada generasi muda melalui lembaga pendidikan sekolah.Menurut Hamalik (2010:61) pembelajaran merupakan upaya mengorganisasi lingkungan untuk menciptakan kondisi belajar bagi peserta didik dengan memberikan bimbingan dan menyediakan berbagai kesempatan yang dapat mendorong siswa belajar untuk memperoleh pengalaman sesuai dengan tujuan pembelajaran.Pembelajaran merupakan interaksi terus menerus yang dilakukan individu dengan linkungannya, dimana lingkungan tersebut mengalami perubahan.Dengan adanya interaksi dengan lingkungan, maka fungsi intelektul semakin berkembang.Dari berbgai pandangan para ahli pendidikan dapat disimpulkan bahwa pembelajaran merupakan kegiatan yang dilakukan guru untuk membelajarkan siswa secara aktif yang menekankan pada penyediaan sumber belajar (Isjoni, 2007:12). Mata pelajaran IPS

\section{METODE PENELITIAN}

Penelitian tentang pembelajaran IPS berbasis pendidikan multikultural di SMP Negeri 1 Lasem merupakan penelitian kualitatif. Metode penelitian kualitatif ini dilakukan secara intensif pada kondisi yang alamiah. Fokus dalam penelitian ini adalah nilai-nilai multikultural dalam masyarakat Lasem, penerapan pembelajaran IPS berbasis pendidikan multikultural, faktor pendukung dan penghambat dalam penerapan pembelajaran IPS berbasis pendidikan multikultural di SMP Negeri 1 Lasem.

\section{HASIL PENELITIAN DAN PEMBAHASAN}

\section{Sejarah Kota Lasem}

Lasem sebuah kota pelabuhan yang menjadi pintu masuk bagipara pendatang. Sebelum kedatangan VOC, Lasem telah berkembang sebagai kota dagang. Banyak pedagang terutama pedagang Tionghoa yang berdagang di Lasem dan lama kelamaan membentuk permukiman di Lasem. Tiga buah kelenteng, yakni Klenteng $\mathrm{Cu}$ An Kiong di Dasun, Klenteng Poo An Bio di Karangturi, Klenteng Gie Yong Bio di Babagan dan arsitektur bangunan rumah tinggal bergaya Tionghoa, serta ritual budaya Tionghoa menjadi salah satu ciri dari Lasem.

Di samping sebagai kota "Tiongkok Kecil”, Lasem juga menjadi pusat penyebaran agama Islam sejak masa kerajaan. Lasem juga dikenal sebagai kota santri yang memiliki jaringan 
penyebaran Islam melalui pesantren dan santrinya. Budaya atau tradisi yang berbasis pesantren seperti kegiatan haul (peringatan ulang tahun kematian ulama yang dihormati), pembacaan riwayat hidup ( manaqib ) dan pengajian mewarnai kehidupan di pesantren dan lingkungan sekitar.

Dalam penyebaran Islam, peran Mbah Sambu (Sayyid Abdurrahman bin Muhammad Hasyim bin Abdurrahman Basyaiban), yang memiliki garis keluarga di Hadramaut, Yaman memiliki andil yang cukup besar. Pada masa Mbah Sambu ditandai dengan pembangunan masjid di tengah kota, di depan alun-alun Lasem pada tahun 1588. Masjid itu sekarang dikenal dengan nama Masjid Jami' Lasem. Pada abad XX juga muncul seorang ulama besar di Lasem yaitu K.H. Ma' soem atau dikenal sebagai Mbah Ma’ soem.

Lasem berkembang menjadi kota pelabuhan, dan mengubah daerah tersebut menjadi daerah multikultur dan membentuk masyarakat yang menjunjung tinggi nilai - nilai toleransi dari pluralisme. Interaksi antara warga Tionghoa, Arab, dan Jawa yang terjalin cukup lama. Hubungan dan interaksi antaretnis itu berjalan secara dinamis. Keragaman budaya yang berkembang di Lasem merupakan dinamika sosial, politik, dan ekonomi yang pada gilirannya membentuk sebuah akulturasi, harmoni dan kohesi sosial di Lasem pada masa kini.

Kedekatan tempat tinggal (lokasi), perkawinan antaretnis yang terjalin cukup lama mendapatkan momentum tatkala terjadi peristiwa Perang Kuning (1740-1743). Perang tersebut awalnya terjadi di Batavia yakni pembantaian orang-orang Tionghoa oleh Kompeni, peristiwa itu terus menjalar dan kemudian sampai di Lasem. Kolaborasi antara Oey Ing Kiat, R.P Margana, dan Kiai Baidawi yang memerangi Kompeni menjadi titik yang menentukan dalam hubungan antara Jawa, Santri, dan Tionghoa. Ketiga tokoh tersebut menjadi simbol pemersatu Lasem yang oleh masyarakat Lasem terus diingat hingga sekarang. Ikatan persaudaraan dan kerj asama kedua etnis tersebut selalu direproduksi oleh masyarakat setempat untuk mendorong atau merekayasa terbentuknya harmoni sosial budaya di Lasem. Cerita tentang prajurit gagah berani dan membela masyarakat, Oey Ing Kiat dan Panji Margana menjadi simbol bersatunya pribumi dan Tionghoa. Keberadaan tokoh-tokoh itu diakui oleh masyarakat Lasem dan selalu dibanggakan oleh warga.

\section{Pelaksanaan Pembelajaran IPS Berbasis Pendidikan Multikultural di SMP Negeri 1 Lasem}

\section{a. Perencanaan Pembelajaran}

Dalam suatu pembelajaran, persiapan diperlukan untuk membuat pembelajaran terencana dengan baik dan tepat agar mampu menghasilkan suatu pembelajaran yang efektif. Dalam melakukan perencanaan pembelajaran tersebut dimulai dari pengembangan program hingga persiapan pembelajaran itu sendiri. Berdasarkan hasil wawancara dan observasi serta studi dokumentasi dapat diketahui persiapan pembelajaran yang dilakukan oleh guru IPS SMP Negeri 1 Lasem. Secara garis besarnya meliputi sebagai berikut : 
1) Pengembangan program

Langkah pertama persiapan pembelajaran yang dilakukan oleh guru mata pelajaran IPS pada SMP Negeri 1 Lasem adalah melakukan pegembangan program. Pengembangan program mencakup program tahunan, program semester, program mingguan dan harian, program pengayaan dan remedial. Sebagaimana diungkapkan oleh Guru IPS SMP Negeri 1 Lasem sebagai berikut.

Hal pertama yang dilakukan adalah persiapan pembelajaran. Dalam hal ini dilakukan perencanaan dengan membuat perangkatperangkat penunjang kegiatan akademik, seperti Prota, Promes, Program Mingguan, dan Harian. Itu biasanya disiapkan di awal(Wawancara Guru IPS, Bapak Suwondo tanggal 29 Juli 2017)

Studi dokumen yang telah dilakukan peneliti, tampak bahwa program tahunan atau yang biasa disebut dengan prota dipersiapkan dan dikembangkan setiap awal tahun ajaran dengan pola yang umum sebagai pedoman untuk mengambangkan program-program lainnya yang lebih rinci. Program semester atau yang biasa disebut promes merupakan program yang lebih rinci dari program tahunan. Promes berisikan garis besar mengenai halhal yang hendak dilaksanakan dan akan dicapai dalam satu semester.

Program semester yang disusun oleh guru SMP Negeri 1 Lasem berisikan tentang urutan bulan, pokok bahasan yang hendak disampaikan, alokasi waktu serta keteranganketerangan.

Program mingguan dan harian merupakan penjabaran dari program semester. Dari program ini dapat teridentifikasi siswa-siswa yang mengalami kesulitan belajar, akan dilayani melalui kegiatan remedial, sedangkan untuk siswa yang cemerlang akan dilayani melalui kegiatan pengayaan agar siswa mempertahankan kecepatan belajarnya.

Program pengayaan dan remidial merupakan pelengkap dan penjabarandari program mingguan dan harian. Program ini dilaksanakan berdasarkan hasil analisis terhadap kegiatan belajar dan terhadap tugas, hasil tes, dan ulangan.

Guru IPS memandang hal ini penting sebagai upaya guru memahami perkembangan peserta didik dan kemudian melakukan bimbingan secara intensif. Lebih lanjut guru IPS mengungkapkan bahwa saat pembelajaran, kita dapat mengetahui perkembangan peserta didik baik dari bakat maupun potensinya. Berdasarkan perangkat pembelajaran, guru dapat mengadakan tindak lanjut atas kondisi peserta didik dengan melakukan remedial pada siswa yang nilainya tidak tuntas KKM dan melakukan pengayaan pada siswa yang nilainya sudah tuntas (Wawancara Guru IPS, Bapak Suwondo tanggal 29 Juli 2017).

2) Pengembangan perangkat pembelajaran 
Sebagai persiapanmengajar, guru mata pelajaran IPS SMP Negeri 1 Lasem melakukan pengembangan atas silabus dan Rencana Pelaksanaan Pembelajaran (RPP) yang telah ditetapkan pemerintah melalui buku ajar guru. Silabus adalah rencana pembelajaran pada suatu kelompok mata pelajaran dengan tema tertentu. Silabus yang disusun mencakup standar kompetensi, kompetensi dasar, materi pembelajaran, kegiatan pembelajaran, indikator, penilaian, alokasi waktu, dan sumber belajar yang dikembangkan oleh setiap satuan pendidikan. Dalam Kurikulum 2013, silabus telah disiapkan oleh pemerintah.

RPP merupakan perencanaan jangka pendek untuk memperkirakan atau memproyeksi apa yang akan dilakukan dalam pembelajaran. Rencana Pelaksanaan Pembelajaran (RPP) berisi tentang : alokasi waktu, standar kompetensi, kompetensi dasar, indikator, tujuan pembelajaran, materi pokok, serta penilaian.

Dalam buku ajar pegangan guru yang disediakan pemerintah, di dalamnya telah terdapat Rencana Pelaksanaan Pembelajaran (RPP). Guru dalam hal ini cukup melakukan pengembangan yang diperlukan. Hal ini selaras dengan keterangan dari guru IPS sebagai berikut, bahwa di dalam buku ajar sudah terdapat Standar Kompetensi, Kompetensi Inti, sampai indikator. Jadi guru tinggal mengikuti, menyesuaikan kondisi di kelas dan melakukan pengembangan seperlunya (Wawancara Guru IPS, Ibu Endiyati tanggal 21 Juli 2017).

Pembelajaran berwawasan multikultural ini dapat diterapkan dalam pembelajaran IPS, dimana kajian IPS sangat erat sekali dengan kebudayaan, lingkungan dan kehidupan bermasyarakat. Mata pelajaran IPS di SMPkelas VIII, salah satu Kompetensi Inti (KI) dalam materinya adalah keragaman sosial budaya.Kompetensi dasar materi ini antara lain (1.1) Menghayati karunia tuhan YME yang telah menciptakan waktu dengan segala perubahannya (1.2) Menghayati ajaran agama dalam berfikir dan berperilaku sebagai penduduk Indonesia dengan mempertimbangkan kelembagaan social, budaya, ekonomi, dan politik dalam masyarakat (1.3) Menghayati karunia Tuhan yang telah menciptakan manusia dan lingkungan (2.2) Memiliki rasa ingin tahu, terbuka dan sikap kritis terhadap permasalahan social sederhana (2.3) Menunjukkan perilaku santun, peduli dan menghargai perbedaan pendapat dalam interaksi social dengan lingkungan dan teman sejawat (3.3) Mendiskripsikan fungsi dan peran kelembagaan social, budaya, ekonomi dan politik dalam masyarakat (3.4) Mendiskripsikan bentuk-bentuk dan sifat dinamika interaksi manusia dengan lingkungan social, alam, budaya dan ekonomi di lingkungan masyarakat sekitar (4.3) Menyajikan hasil pengamatan bentuk-bentuk dinamika interaksi manusia dengan lingkungan alam, sosial, budaya, dan ekonomi di lingkungan masyarakat sekitar. (Silabus SMP Negeri 1 Lasem). 


\section{b. Pelaksanaan Pembelajaran IPS Berbasis Pendidikan Multikultural}

Perpsektif multikultural sangat urgen, hal ini mempengaruhi prasangka etnis, fanatisme rasial maupun tendensi untuk mengunggulkan golongannya sendiri. Stork memaparkan bahwa penggunaan unsur-unsur universal manusia sangat penting dalam mendukung keberhasilan pengajaran pendidikan multikultural. Unsur-unsur universal menurut Stork merupakan segala apa yang secara umum dimiliki oleh setiap orang, seperti kebutuhan akan rasa aman, kebutuhan untuk saling mengenal dan dikenal, kebutuhan untuk diakui maupun keinginan untuk memenuhi kebutuhan ( Elizabeth Stork, 2008).

Pemahaman mengenai multikultural di sekolah bertujuan membentuk peserta didik yang memiliki pengetahuan dan nantinya dapat sesuai dengan tujuan pembelajaran IPS. Guru memegang peran yang strategis dalam peningkatan mutu pendidikan, seperti pembaharuan kurikulum, pengembangan metode mengajar, maupun penyediaan sarana dan prasarana yang melibatkan peran guru didalamnya (Musadad dan Wasino, 2012:227).

Berdasarkan hasil observasi dan pengamatan yang dilakukan di SMP Negeri 1 Lasem pada Juli-Agustus 2017, dalam pelaksanaan kegiatan pembelajaran IPS menggunakan kurikulum 2013. Guru mengaplikasikan media power point dan metode diskusi kelas. Dalam pembelajaran IPS, dilakukan di luar kelas maupun di dalam kelas. Pelaksanaan pembelajaran IPS sudah berjalan dengan baik. Guru membangkitkan keaktifan siswa dengan diskusi, presentasi dan tanya jawab. Dengan permulaan guru menyampaikan topik dan tujuan pembelajaran kepada siswa dan siswa kemudian dipancing dengan gambar. Selanjutnya diberikan waktu untuk menggali informasi sebanyak-banyaknya. Kemudian siswa diperbolehkan bertanya kepada guru jika ada materi yang kurang dimengerti. Kemudian guru membentuk kelas dalam beberapa kelompok kemudian mengerjakan soal untuk didiskusikan dengan kelompoknya, selanjutnya tiap-tiap kelompok melakukan presentasinya. Setelah kegiatan presentasi selesai umumnya guru merangkum hasil presentasi kemudian menutup pelajaran dengan mengulas materi yang telah dipelajari dan jika masih ada sisa waktu guru memberikan penugasan untuk pertemuan selanjutnya. Dalam pendekatannya yaitu pendekatan scientific yang meliputi mengamati, menanya, menalar, mencoba, dan membentuk jejaring/menyajikan sudah berjalan walaupun masih sederhana.

Metode yang diaplikasikan dalam pembelajaran IPS berbasis multikultural di SMP N 1 Lasem yaitu Problem Based Learning (PBL). Menurut Barbara J. Duch (1996), Problem Based Learning (PBL) adalah satu model yang ditandai dengan penggunaan masalah yang ada di dunia nyata untuk melatih siswa berfikir kritis dan terampil memecahkan masalah, dan memperoleh pengetahuan tentang konsep yang penting dari apa yang dipelajari (Wijayanto, 2009:15). 
Umumnya, metode ini akan mengenalkan siswa pada suatu kasus yang memiliki keterkaitan dengan materi yang dibahas. Kemudian, siswa akan diminta agar mencari solusi untuk menyelesaikan kasus/masalah tersebut. Selain itu, metode ini akan meningkatkan kecakapan berpartisipasi dalam tim.Metode ini merupakan suatu pendekatan pembelajaran yang berusaha menerapkan masalah yang terjadi di dunia nyata. Dengan ini, siswa akan dilatih berpikir kritis serta menemukan solusi. Ada enam ciri, di antaranya:

1. Kegiatan belajar dimulai dengan pemberian sebuah masalah.

2. Masalah yang disuguhkan masih berkaitan dengan kehidupan nyata para siswa.

3. Mengorganisasikan pembahasan seputar masalah, bukan disiplin ilmu.

4. Siswa diberi tanggung jawab maksimal dalam menjalankan proses belajar secara langsung.

5. Siswa dibagi menjadi beberapa kelompok kecil, terjadi kolaborasi.

6. Siswa harus mendemonstrasikan kinerja yang sudah dipelajari.

Langkah-Langkah Penggunaan Model Pembelajaran PBL yaitu :

a. Konsep Dasar (Basic Concept)

Fasilitator memberikan konsep dasar, petunjuk, referensi, atau link dan skill yang diperlukan dalam pembelajaran tersebut. Hal ini dimaksudkan agar peserta didik lebih cepat masuk dalam atmosfer pembelajaran dan mendapatkan peta yang akurat tentang arah dan tujuan pembelajaran.

b. Pendefinisian Masalah (Defining The Problem)

Dalam langkah ini fasilitator menyampaikan scenario atau permasalahan dan peserta didik melakukan berbagai kegiatan brainstorming dan semua anggota kelompok mengungkapkan pendapat, ide, dan tanggapan terhadap scenario secara bebas, sehingga dimungkinkan muncul berbagai macam alternative pendapat.

c. Pembelajaran Mandiri (Self Learning)

Peserta didik mencari berbagai sumber yang dapat memperjelas isu yang sedang dinvestigasi. Sumber yang dimaksud dapat dalam bentuk artikel tetulis yang tersimpan dipepustakaan, halaman web, atau bahkan pakar dalam bidang yang relevan. Tahap investigasi memiliki dua tujuan utama,yaitu: (1) agar peserta didik mencari informasi dan mengembangkan pemahaman yang relevan dengan permasalahan yang telah didiskusikan dikelas, dan (2) informasi dikumpulkan dengan satu tujuan yaitu dipresentasikan di kelas dan informasi tersebut haruslah relevan dan dapat dipahami.

d. Pertukaran Pengetahuan (Exchange Knowledge)

Setelah mendapatkan sumber untuk keperluan pendalaman materi dalam langkah pembelajaran mandiri, selanjutnya pada pertemuan berikutnya peserta didik berdiskusi 
dalam kelompoknya untuk mengklarifikasi capaiannya dan merumuskan solusi dari permasalahan kelompok. Pertukaran pengetahuan ini dapat dilakukan dengan cara peserta didik berkumpul sesuai kelompok dan fasilitatornya.

e. Penilaian (Assessment)

Penilaian dilakukan dengan memadukan tiga aspek pengetahuan (knowledge), kecakapan (skill), dan sikap (attitude). Penilaian terhadap penguasaan pengetahuan yang mencakup seluruh kegiatan pembelajaran yang dilakukan dengan ujian akhir semester (UAS), ujian tengah semester (UTS), kuis, PR, dokumen, dan laporan.

Dalam penerapan metode ini peserta didik diajak berpartisipasi dalam memahami dan mengapresiasi kultur lain. Metode ini antara lain dengan menyertakan peserta didik memilih buku bacaan bersama, melakukan aktivitas bersama. Mengapresiasikan even-even bidang keagamaan maupun kebudayaan yang terdapat dalam kehidupan masyarakat. Peserta didik bisa melibatkan diri didalam pelajaran atau pengalaman yang berkaitan dengan peristiwa ini. Namun perhatian yang sedikit juga diberikan kepada kelompok-kelompok etnik baik sebelum dan sesudah event atau signifikan budaya dan sejarah peristiwa bisa dieksplorasi secara mendalam. Dalam penerapan metode ini, guru menambahkan metode lawatan sejarah dengan aksi melakukan kunjungan pada obyek-obyek dan situs-situs sejarah bernilai multikultural. Contohnya etnis Cina anak-anak Cina itu diajak untuk mempelajari nembang, mocopat, tari Jawa,membatik, mengenal kultur budaya Jawa. Begitu juga sebaliknya anak-anak jawa juga diajari untuk mengenal tradisi cina seperti main barongsai, tradisi dalam imlek, cap go meh, samsi. Jadi mereka dikenalkan dengan tari barongsai, leang leong, tradisi Cina. Mengunjungi kota-kota sejarah yang berdasarkan kultur Cina seperti klenteng, tiongkok kecil. Etnis cina juga diajak kunjungan lawatan ke tempat-tempat yang berbau budaya jawa dan juga islam. Contohnya pasujudan sunan bonang, maulud nabi, bende becak, perayaan-perayaan yang berdasarkan kultur Jawa dan Islam. Bahkan dari hal tersebut juga dapat melahirkan suatu akulturasi budaya. Guru juga memperkenalkan bentuk akulturasi budaya dalam tata cara berpakaian dalam adat pernikahan di Lasem, musik, makanan.

\section{Faktor Pendukung dan Penghambat Dalam Penerapan Pembelajaran IPS Berbasis Pendidikan Multikultural di SMP Negeri 1 Lasem.}

\section{a. Faktor Pendukung}

1) Faktor agama

Faktor agama sangat berpengaruh besar dalam penerapan pembelajaran IPS berbasis multikultural. Pada kenyataannya, keadaan daerah Lasem yang memang masyarakatnya sebagian adalah masyarakat dari keturunan cina, orang hindu dan budha. 
Keberadaan SMP Negeri 1 Lasem menjadi daya tarik tersendiri bagi mereka yang ingin menyekolahkan anak anaknya di SMP Negeri 1 Lasem yang menerima siswa dari berbagai agama.

2) Faktor suku

Siswa siswi SMP Negeri 1 Lasem juga berasal dari suku Jawa, Cina dan mempunyai budaya yang berbeda beda pula.Inilah yang menjadi faktor pendukung penerapan pembelajaran IPS berbasis multikultural di SMP Negeri 1 Lasem.

3) Faktor budaya

Faktor budaya yang dimiliki oleh tiap siswa seperti budaya kesenian tari dan kesenian barongsai. Siswa yang berasal dari suku jawa biasanya sangat berminat untuk bermain kesenian tari-tarian jawa. Sedangkan siswa yang berasal dari keturunan cina gemar memainkan kesenian barongsai. Namun, hal tersebut tidak menutup kesempatan bahwa anak non islam tidak boleh bermain tari tarian Jawa ataupun anak islam tidak boleh bermain barongsai.

4) Dukungan dari masyarakat sekitar sekolah

Dukungan masyarakat sekitar sangat dibutuhkan agar sekolah ini tetap berjalan sebagaimana mestinya dan tetap ada sampai kapanpun untuk menciptakan multikulturalisme bagi masyarakat Lasem sendiri. Pandangan bahwa tidak ada penggolongan dan pembedaan antara kelas atas dan kelas bawah, etnis jawa dan cina, faktor mayoritas dan minoritas mampu disejajarkan tanpa membeda-bedakan.

Faktor pendukung penerapan pembelajaran IPS berbasis multikultural di SMP Negeri 1 Lasem tidak hanya karena aneka ragam agama dan budaya yang dimiliki siswa siswinya saja. Namun dengan adanya aneka ragam tersebut terciptalah rasa saling menghargai dan menghormati ditengah perbedaan yang dimiliki siswa SMP Negeri 1 Lasem. Sikap saling menghargai dan menghormati antar siswa tidak hanya dapat dijumpai dalam kegiatan belajar di sekolah saja. Namun, terlebih ketika ada perayaan hari besar agama ataupun bulan puasa Islam dapat terlihat jelas bagaimana kerukunan umat beragama saling menghargai dan menghormati dengan umat beragama yang berbeda.

Berdasarkan pengamatan peneliti dan hasil wawancara dengan guru dan siswa mengenai faktor pendukung penerapan pembelajaran IPS berbasis multicultural di SMP Negeri 1 Lasem dapat disimpulkan yaitu faktor agama, faktor suku, faktor budaya, dukungan masyarakat sekitar, saling menghargai dan menghormati antar sesama. Selain faktor faktor pendukung tersebut, masih terdapat faktor pendukung yang lebih signifikan yaitu guru guru SMP Negeri 1 Lasem yang mempunyai rasa toleransi 
terhadap siswa, aturan sekolah yang tidak diskriminasi, rapat atau musyawarah pertemuan antara pihak sekolah dengan orangtua siswa, pembauran seni budaya antara Jawa dan Thionghoa, perayaan hari besar agama, saling bantu membantu dalam persiapan kegiatan agama, serta animo masyarakat yang sangat antusias terhadap sekolah. Perbedaan semua itu tidak menjadi penghalang bagi siswa siswi SMP Negeri 1 Lasem untuk tetap menjaga kerukunan, berinteraksi dengan sesama, menumbuhkan rasa saling menghargai dan menghormati terhadap sesama.

\section{b. Faktor penghambat}

1. Kendala internal

Dalam suatu proses pembelajaran di sekolah, tentu para pendidik mempunyai kendala tersendiri yang dihadapi dalam menyampaikan materi yang guru sampaikan kepada peserta didik. Setiap pendidik mempunyai kendala yang berbeda-beda dalam kegiatan pembelajaran. Apalagi kondisi sekolah yang berbeda dengan sekolah pada umumnya. Terlebih SMP Negeri 1 Lasem merupakan sekolah negeri yang memiliki siswa siswi yang banyak memeluk agama yang berbeda-beda, mereka juga mempunyai latar belakang yang berbeda pula. Keadaan inilah yang membuat para pendidik menghadapi kendala tersendiri dalam proses belajar mengajar di sekolah. Kendala yang pendidik hadapi salah satunya adalah kendala internal. Kendala internal ini bisa berasal dari saat siswa belajar dikelas, siswa saat bermain di jam istirahat atau dari segala yang ada di lingkungan sekolah. Pada waktu peneliti melakukan pengamatan di dalam kelas, peneliti mengamati cara guru mengajar dikelas, cara guru memberikan pemahaman serta cara bagaimana guru mengatasi kondisi kelas saat tidak kondusif di tengah-tengah siswa yang memiliki beragam perbedaan. Selain pengamatan di kelas, peneliti juga melakukan wawancara langsung dengan guru kelas untuk mendapatkan informasi kendala apakah yang dihadapi para guru pada saat mengajar siswa dikelas. Berdasarkan pengamatan peneliti pada waktudikelas, ada kejadian seorang siswa tiba-tiba sedikit mengamuk terhadap temannya. Kemudian siswa itu diperingatkan oleh gurunya dengan teguran.

Usia anak yang tergolong masih seumuran anak SMP tentunya masih labil tingkat emosi dirinya. Siswa masih perlu pengawasan lebih bila sedang berada di sekolah maupun di luar sekolah. Siswa yang masih belia ini sangat mudah terpengaruh. Pengaruh yang sifatnya negatif inilah yang menjadi kekhawatiran bagi para pendidik di sekolah terhadap perkembangan anak didiknya. Penekanan terhadap sikap toleransi beragama sangat penting bagi siswa siswi SMP N 1 Lasem dengan melihat kondisi siswa yang mempunyai banyak agama yang di anut. Maka dari itu, para pendidik harus 
selalu memberi pemahaman yang lebih terhadap siswa tentang sikap toleransi beragama. Sekolah dan para guru mempunyai peran yang penting dalam hal memotivasi siswa tentang sikap toleransi beragama.

Jadi jelas bahwa peran sekolah dan para guru sangat penting bagi siswa dalam memahami sikap toleransi beragama antar sesama. Berdasarkan pengamatan peneliti, pada saat melakukan penelitian di kelas terdapat suatu kejadian ketika siswa dibagi beberapa kelompok untuk melakukan diskusi, ada siswa etnis Thionghoa yang tidak mau menerima pendapat siswa etnis Jawa. Dia kokoh dengen pemikirannya sendiri, tidak mau menerima pendapat dari siswa etnis Jawa. Dalam pergaulan di sekolah, siswa dengan latar belakang etnis keturunan Thionghoa dengan perekonomian yang lebih tinggi cenderung memilih dan bergaul dengan teman yang memiliki latar belakang etnis dan perekonomian yang sama.

Menjadi seorang pendidik tentunya mempunyai kendala terbesar dalam melakukan kegiatan belajar mengajar. Kendala terbesar yang dihadapi pendidik tentunya berbeda satu dengan lainnya, terlebih anak didik yang dihadapi adalah anak anak yang mempunyai perbedaan dari segi agama, suku, dan budaya. Namun berdasarkan hasil penelitian yang peneliti lakukan terhadap para guru IPS, justru mereka mengungkapkan tidak menemui kendala terbesar apapun dalam menghadapi siswa siswi yang banyak mempunyai perbedaan tersebut.

Kurangnya ketersediaan sarana prasarana seperti LCD di SMP Negeri 1 Lasem, sehingga tidak mendukung pembelajaran dengan baik.Selain itu, kendala yang lain juga terdapat pada salah satu guru IPS yang kompetensinya kurang saat menjelaskan pelajaran, jadi siswa kurang memahami.

Berdasarkan penelitian yang dilakukan peneliti di lapangan maka dapat disimpulkan bahwa kendala internal yang dihadapi pendidik dalam proses pembelajaran adalah hubungan antar siswa yang terkadang berselisih saat diskusi di kelas, karakteristik siswa yang berbeda-beda, motivasi belajar siswa, pemahaman terhadap toleransi beragama, kurangnya sarana prasarana serta guru IPS yang kompetensinya kurang dalam menjelaskan.

2. Kendala Eksternal

Kendala yang dihadapi pendidik dalam proses pembelajaran siswa tidak hanya ada pada saat di dalam kelas saja. Namun, kendala yang datang dari luar juga ada. Bahkan apabila kendala yang dari luar ini di pandang sebelah mata dan tidak diberikan perhatian khusus justru akan menimbulkan dampak negatif yang besar terhadap perkembangan anak. Kendala ini dapat berupa pengaruh lingkungan rumah siswa yang 
kurang baik, dan dapat juga yang berasal dari tugas yang diberikan guru kepada siswa secara berkelompok yang tidak dilakukan siswa secara baik dan benar.

Kendala lain yang dihadapi pendidik dari luar sekolah adalah keretakan hubungan yang terjadi bukan dari siswa, justru keretakan hubungan yang datang dari orang tua siswa sendiri. Keretakan hubungan orang tua yang berkelanjutan ini sangat tidak dibenarkan. Dengan adanya keretakan hubungan orang tua yang seperti ini justru nantinya akan berdampak negatif bagi hubungan antar siswa juga yang sudah terjalin baik dan rukun.

Kendala yang harus dihadapi pendidik tidak sampai disitu saja. Kendala lain yang harus mendapatkan perhatian adalah rasa tanggung jawab siswa yang mempunyai kewajiban untuk belajar. Rasa tanggung jawab inilah yang perlu mendapat perhatian khusus, dimana lingkungan luar sangat berpengaruh bagi perkembangan anak. Jika anak tidak diberikan perhatian secara benar, maka lingkungan luar anak membawa dampak yang negatif. Pengaruh dari lingkungan luar ini dapat berupa pergaulan anak yang salah, pengaruh internet, pengaruh perkembangan teknologi, acara televisi yang tidak mendidik dan sebagainya. Jika rasa tanggung jawab anak sebagai siswa untuk belajar mulai terkikis, maka anak akan tumbuh rasa malas untuk mengerjakan PR dan malas belajar.

Maka berdasarkan pengamatan yang dilakukan oleh peneliti serta wawancara dengan guru kelas dan Kepala SMP Negeri 1 Lasem tentang kendala yang dihadapi pendidik dari luar sekolah dapat ditarik kesimpulan yaitu terkadang tugas kelompok dari guru tidak dikerjakan dengan anggota kelompok yang datang semuanya, terjadi keretakan hubungan antara orang tua siswa ketika siswa bertengkar namun siswa sudah berdamai tapi orang tua masih saling berselisih, dan pengaruh dari lingkungan luar yang dapat berupa pergaulan teman yang salah, pengaruh internet, acara televisi yang tidak mendidik, perkembangan teknologi dan sebagainya.

SMP Negeri 1 Lasem mempunyai siswa siswi yang beraneka ragam budaya dan agama. Keberagaman agama, etnis, dan budaya yang dimiliki oleh siswa siswi di sekolah tersebut berdampak besar pada pola pergaulan di lingkungan sekolahmaupun diluar sekolah.Sudah barang tentu guru sebagai tenaga pendidik di sekolah tersebut telah mempunyai cara dalam menyadari dan memahami keberagaman yang dimiliki anak didiknya dalam proses pembelajaran di kelas maupun di luar kelas, yaitu dengan cara nilainilai multikultural tersebut dimasukkan dalam pembelajaran IPS di sekolah. Pembelajaran IPS di sekolah yang berwawasan multikultural dimasukkan dalam kurikulum IPS di SMP Negeri 1 Lasem.Guru mengetahui jumlah komposisi etnis pada kelas tersebut lalu 
memberikan pemahaman tentang berbagai budaya melalui mata pelajaran IPS tanpa harus memaksa siswa untuk menyukai budaya etnis lain. Guru juga membuat suatu inovasi baru dalam metode pembelajaran IPS yang berkaitan dengan pendidikan multikultural sehingga siswa mengetahui berbagai budaya dan mengahargai budaya etnis lain.

Hal ini sesuai dengan Teori Pendidikan Multikultural James A. Banks. Ia mrnyatakan bahwa pendidikan multikultural sebagai pendidikan untuk people of color. Artinya, pendidikan multikultural ingin mengeksplorasi perbedaan sebagai keniscayaan (anugerah Tuhan/sunatullah). Pendidikan multikultural memiliki beberapa dimensi yang saling berkaitan satu dengan yang lain, yaitu : Pertama, Content Intergration, yaitu mengintegrasikan berbagai budaya dan korealisasi dan teori dalam mata pelajaran/disiplin ilmu. Kedua, the knowledge construction process, yaitu membawa siswa untuk memahami implikasi budaya ke dalam sebuah mata pelajaran ( disiplin ). Ketiga,an equity paedagogy, yaitu menyesuaikan metode pengajaran dengan cara belajar siswa dalam rangka memfasilitasi prestasi akademik siswa yang beragam baik dari segi ras, budaya ataupun sosial. Keempat, prejudice reduction, yaitu mengidentifikasi karakteristik ras siswa dan menetukan metode pengajaran mereka.

Keterlibatan guru mata pelajaran IPS lewat pembelajaran IPS yang ada di SMP Negeri 1 Lasem memberikan pengetahuan yang lebih kepada siswa bagaimana berinteraksi dengan teman sebayanya dalam lingkup multikultur.Metode yang diaplikasikan dalam pembelajaran IPS berbasis multikultural di SMP N 1 Lasem yaitu metode Problem Based Learning (PBL). Dalam penerapan metode ini peserta didik diajak berpartisipasi dalam memahami dan mengapresiasi kultur lain. Metode ini antara lain dengan menyertakan peserta didik memilih buku bacaan bersama, melakukan aktivitas bersama. Mengapresiasikan even-even bidang keagamaan maupun kebudayaan yang terdapat dalam kehidupan masyarakat. Peserta didik bisa melibatkan diri didalam pelajaran atau pengalaman yang berkaitan dengan peristiwa ini. Namun perhatian yang sedikit juga diberikan kepada kelompok-kelompok etnik baik sebelum dan sesudah event atau signifikan budaya dan sejarah peristiwa bisa dieksplorasi secara mendalam. Dalam penerapan metode ini, guru menambahkan metode lawatan sejarah dengan aksi melakukan kunjungan pada obyek-obyek dan situs-situs sejarah bernilai multicultural. Contohnya etnis Cina anak-anak Cina itu diajak untuk mempelajari nembang, mocopat, tari jawa, membatik, mengenal kultur budaya Jawa. Begitu juga sebaliknya anak-anak jawa juga diajari untuk mengenal tradisi cina seperti main barongsai, tradisi dalam imlek, cap go meh, samsi. Jadi mereka dikenalkan dengan tari barongsai, leang leong, tradisi Cina. Mengunjungi kota-kota sejarah yang berdasarkan kultur cina seperti klenteng, tiongkok kecil. Etnis cina juga diajak kunjungan 
lawatan ke tempat-tempat yang berbau budaya jawa dan juga islam. Contohnya pasujudan sunan bonang, maulud nabi, bende becak, perayaan-perayaan yang berdasarkan kultur jawa dan islam. Bahkan dari hal tersebut juga dapat melahirkan suatu akulturasi budaya. Sehingga materi pembelajaran IPS berbasis multikultural teraplikasi dengan baik di SMP Negeri 1 Lasem. Hasilnya kesadaran siswa dalam pembelajaran IPS berbasis pendidikan multikultural meningkat tapi hasil di lapangan semu formalitas yaitu hanya diterima sebagai formalitas.

\section{E. SIMPULAN}

Berdasarkan paparan di atas dapat disimpulkan:

1. nilai-nilai multikultural yang ada dalam masyarakat Lasem yaitu nilai kemanusiaan, nilai toleransi dalam hidup bermasyarakat, nilai tolong menolong, nilai keadilan, dan nilai gotong royong.

2. Pendidikan multikultural di dalam pembelajaran IPS, nilai karakter yang berusaha ditonjolkan adalah nilai toleransi dan tenggang rasa.

3. Faktor pendukung penerapan pembelajaran IPS berbasis multikultural di SMP Negeri 1 Lasem yaitu faktor agama, faktor suku, faktor budaya, dukungan masyarakat sekitar, sikap saling menghargai dan menghormati antar sesama. Sedangkan faktor penghambatnya antara lain kendala internal yang dihadapi pendidik dalam proses pembelajaran dan kendala eksternal yaitu tugas kelompok dari guru yang tidak dikerjakan secara bersama-sama denganseluruh anggota kelompok.

\section{DAFTAR PUSTAKA}

Al Arifin, Akhmad Hidayatullah. 2012. "Implementasi Pendidikan Multikultural Dalam Praksis Pendidikan Di Indonesia”. Jurnal Pembangunan Pendidikan : Vol. 1, No. 1

Ata Ujan, Andre, dkk. 2009. Multikulturalisme:Belajar Hidup Bersama dalam Perbedaan. Jakarta: PT INDEKS

Aziz, Munawar. 2014. Lasem Kota Tiongkok kecil: Interaksi Tionghoa, Arab, dan Jawa dalam Silang Budaya Pesisiran. Yogyakarta : Ombak

Bank, James A, (1985). Teaching Strategies for the Social Studies. New York: Longman, Inc.

Banks, James A. (2007). Educating citizens in amulticultural society. New York:Teachers College Columbia University.

Creswell, J. W. (2010). Research design: pendekatan kualitatif, kuantitatif, dan mixed. Yogjakarta: PT Pustaka Pelajar. 
Depdiknas. 2002. Pendidikan Kontekstual (Contextual Teaching and Learning). Jakarta: Departemen Pendidikan Nasional.

Hamalik, Oemar. (2010). Proses Belajar Mengajar. Jakarta: PT Bumi Aksara.

Ichas Hamid Al-Lamri dan Tuti Istianti Ichas. 2006. Pengembangan Pendidikan

Nilai dalam Pelajaran Pengetahuan Sosial di SD. Jakarta: DEPDIKNAS

Ichsan. 2010. Pendidikan Multikultural di SMP 5 Makassar. Skripsi Prodi Kependidikan Islam Universitas Islam Negeri Sunan Kalijaga.

Isjoni. 2007. Pembelajaran Sejarah Pada Satuan Pendidikan. Bandung: Alfabeta.

Kamus Umum Bahasa Indonesia. Jakarta : Balai Pustaka, 1999.

Kemendikbud RI. 2013 Buku Guru Ilmu Pengetahuan Sosial

Kemendiknas, 2010.Pendidikan Karakter di Sekolah Menengah Atas. Jakarta: Kemendiknas

Mahfud, Choirul. 2016. Pendidikan Multikultural. Yogyakarta: Pustaka Pelajar.

Narwanti, Sri. 2012. Panduan Menyusun Silabus dan Rencana Pelaksanaan Pembelajaran. Yogyakarta: Familia

Pramono, Suwito Eko. 2013. Hakikat Pendidikan Ilmu Pengetahuan Sosial. Semarang: Widya Karya

Sapriya, dkk. (2006). Pembelajaran dan Evaluasi Hasil Belajar IPS. Bandung: UPI PRESS

Sugiono. 2008. Metode Penelitian Kuantitatif, Kualitatif Dan $R \&$ D. Bandung : Alfabeta

Sukmadinata, N. S. 2009. Metode Penelitian Pendidikan. Bandung : PT Remaja Rosdakarya.

Sumaatmadja, N.(2007). Konsep Dasar IPS. Jakarta: UT

Sulaiman,Jusuf.1990. 'Permusiuman Indonesia'. Ensiklopedia Nasional Indonesia. Jilid 13. Jakarta: Rajawali Press.

Suparlan,Parsudi. "Menuju Masyarakat Indonesia yang Multikultural," Makalah. Disampaikan pada Simposium Internasional Bali ke-3, Jurnal Antropologi Indonesia, Denpasar Bali, 1621 Juli 2002

Suyatno, 2009.Menjelajahi Pembelajaran Inovatif, Sidoarjo: Masmedia Buana Pustaka.

Udin S, Winataputra dkk. 2007. Materi dan pembelajaran IPS SD. Jakarta: Universitas Terbuka.

Usman, Nurdin. 2002. Konteks Implementasi Berbasis Kurikulum. Grasindo: Jakarta. 
